\title{
TURONIAN MICROFOSSIL ASSEMBLAGE OF THE EAGLE FORD FORMATION FROM THE LA BOLITA LOCALITY, COAHUILA, NORTHWEST MEXICO
}

\author{
BLENDA ESMERALDA FLORES-CADENAS, ALEJANDRO MONIER-CASTILLO \\ The Mudlogging Company México, Periférico Carlos Pellicer, Cámara 2152, \\ Colonia Punta Brava, Villahermosa, Tabasco, CP-86150, Mexico. \\ blenda_1409@hotmail.com,alemonier1981@gmail.com
}

\author{
ISABEL LÓPEZ-PALOMINO \\ Léxico Estratigráfico de México, Oficinas Centrales, Servicio Geológico Mexicano, Boulevard Felipe Ángeles s/n, \\ Carretera México-Pachuca, km 93.50-4, Colonia Venta Prieta, Pachuca de Soto, Hidalgo, CP-42083, Mexico. \\ isabellopez@sgm.gob.mx \\ BRUNO FERRÉ \\ Dame du Lac 213, 3 rue Henri Barbusse, F-76300 Sotteville-lès-Rouen, France. \\ bruno_ferre@yahoo.fr
}

ARTURO PALMA-RAMÍREZ

Reyna de la Alegría 110, Fraccionamiento Paseo de las Reynas, Mineral de la Reforma, Hidalgo, CP-42184, Mexico. arctoduspr@gmail.com

\author{
JULIO REYES ROMO-RAMÍREZ, CARLOS RENE MUÑOZ-JARAMILLO \\ Gerencia Regional Centro, Servicio Geológico Mexicano, Avenida Mariano Jiménez, No. 469 \\ Colonia Alamitos, San Luis Potosí, S.L.P., CP-78280, Mexico. \\ julioromo@sgm.gob.mx,carlosr.gantz@gmail.com
}

DIANA CONTRERAS-CRUZ

Posgrado en Ciencias Geológicas, Instituto de Geofísica, Universidad Nacional Autónoma de Mexico, Ciudad Universitaria, C.P. 04510, Ciudad de Mexico, Mexico.

diana.dcc19@gmail.com

\begin{abstract}
Late Cretaceous carbonate rocks of the Eagle Ford Formation are widely distributed in north-western Mexico (Nuevo León, Coahuila, Chihuahua) and southern USA (Texas). Around the La Bolita locality, Castaños town (Coahuila State), this unit consists of approximately $31 \mathrm{~m}$ of marine deposits, characterized by thin-bedded, slightly clayey limestones. Within the scope of a microfacial analysis, 20 hand samples were collected from selected limestone levels. Identified microfossil remains are mostly represented by planktonic foraminifers, among which: Planoheterohelix moremani, P. reussi, P. globulosa, Globigerinelloides bollii, Globigerinelloides spp., Muricohedbergella delrioensis, $M$. planispira, Muricohedbergella spp., Whiteinella archaeocretacea, W. aprica, W. baltica, W. brittonensis, W. inornata, W. paradubia, Whiteinella spp., Clavihedbergella moremani, C. simplex, Marginotruncana renzi, $M$. sigali, M. schneegansi, $M$. pseudolinneiana, Marginotruncana spp., Praeglobotruncana algeriana, and Dicarinella canaliculata. There are also abundant calcispheres, such as Risserella rablingae, Pithonella ovalis, and Calcisphaerula innominata; as well as roveacrinoid ossicles (genus Roveacrinus), and unidentified radiolarians. Based on the stratigraphic range of both the genus Marginotruncana and the species Praeglobotruncana algeriana, an early-middle Turonian age is assigned to the studied section. The pelagic microfossil assemblage and the lithological features all suggest deposition of the studied sediments in an open marine platform, with poorly oxygenated, nutrient-rich waters.
\end{abstract}

Keywords: planktonic foraminifers, Cretaceous, Turonian, Eagle Ford Formation, Coahuila, Mexico. 
RESUMO - Rochas carbonáticas do Cretáceo Superior da Formação Eagle Ford são amplamente distribuídas no noroeste do México (Nuevo León, Coahuila, Chihuahua) e sul dos EUA (Texas). Em torno da localidade de La Bolita, cidade de Castaños (Estado de Coahuila), esta unidade consiste em aproximadamente $31 \mathrm{~m}$ de depósitos marinhos, caracterizados por calcários de camada fina e levemente argilosos. No âmbito de uma análise microfaciológica, foram coletadas 20 amostras de mãos de níveis selecionados de calcário. Os restos microfósseis identificados são representados principalmente por foraminíferos planctônicos, dentre os quais: Planoheterohelix moremani, P. reussi, P. globulosa, Globigerinelloides bollii, Globigerinelloides spp., Muricohedbergella delrioensis, M. planispira, Muricohedbergella spp., Whiteinella archaeocretacea, W. aprica, W. baltica, W. brittonensis, W. inornata, W. paradubia, Whiteinella spp., Clavihedbergella moremani, C. simplex, Marginotruncana renzi, M. sigali, M. schneegansi, M. pseudolinneiana, Marginotruncana spp., Praeglobotruncana algeriana, e Dicarinella canaliculata. Também existem calcisferas abundantes, como Risserella rablingae, Pithonella ovalis e Calcisphaerula innominata; bem como ossículos roveacrinoides (gênero Roveacrinus) e radiolários não identificados. Com base na amplitude estratigráfica do gênero Marginotruncana e da espécie Praeglobotruncana algeriana, é atribuída uma idade eo/mesoturoniana para a seção estudada. O conjunto de microfósseis pelágicos e as características litológicas sugerem a deposição dos sedimentos estudados em uma plataforma marinha aberta, com águas pouco oxigenadas e ricas em nutrientes.

Palavras-chave: foraminíferos planctônicos, Cretáceo, Turoniano, Formação Eagle Ford, Coahuila, México.

\section{INTRODUCTION}

The Eagle Ford Formation has been studied for more than 100 years. Roemer (1852) described it first in the Texas area, as black shales with fish remains. Later, Hill (1887, in GEOLEX, 2018) proposed the name of Eagle Ford for a succession of blue clay shales at the top and at the base and yellow ones in the middle, exposed at Eagle Ford, Dallas county, northeastern Texas. Finally, Albritton (1941, in GEOLEX, 2018), instead of the descriptive term, gave it the range of "unit", naming it the Eagle Ford Formation.

This unit is widely distributed in northeastern Mexico (PEMEX, 1988; González-Ramos et al., 1997; SantiagoCarrasco et al., 1998) and from northeastern Texas (USA) to Nuevo León, Coahuila (Santamaría et al., 1991), and Chihuahua (Franco-Rubio, 2007).

Most previous works on the Eagle Ford Formation focused on its paleogeography, structural geology, stratigraphy, and paleontology. Its fossil record is represented by plants, marine reptiles, pterosaurs (Vega-Vera et al., 2007), fishes (BlancoPiñón \& Alvarado-Ortega, 2005; Alvarado-Ortega et al., 2006), ammonites, inoceramids, and decapods (Stinnesbeck et al., 2005; Ifrim et al.; 2007; Vega-Vera et al., 2007).

Moreover, this formation contains an abundant microfauna including foraminifers (Heterohelix globulosa, H. moremani, Globigerinelloides sp., Clavihedbergella amabilis, Clavihedbergella simplex, Thalmaninella appenninica, Ticinella roberti, Rotalipora sp., Archaeoglobigerina bosquensis, A. blowi, A. cretacea, Radotruncana calcarata, Globotruncanita stuarti, Globotruncanella petaloidea, Helvetoglobotruncana helvetica, Marginotruncana renzi, Dicarinella carinata, D. indica, Whiteinella archaeocretacea, Planulina austiniana, Schackoina cenomana), and calcispheres (genera Pithonella and Stomiosphaera) (SilvaMartínez, 2014).

According to the aforementioned studies, the lack of thorough biostratigraphic studies on the Eagle Ford Formation is evident. The purpose of this work is to document the microfossil content occurring in this unit exposed at La Bolita, southeastern Coahuila State; to refine its age assignment as much as possible and finally to reconstruct its paleoenvironmental conditions.

\section{STUDY AREA AND GEOLOGICAL SETTING}

The study area is located in the Castaños municipality, Coahuila State, northeastern Mexico. The outcrop is exposed $6 \mathrm{~km}$ to the southeast of La Bolita common public land, in the surroundings of Lomas Los Piloncillos, geographic coordinates $26^{\circ} 28^{\prime} 29^{\prime \prime} \mathrm{N} / 101^{\circ} 19^{\prime} 42^{\prime \prime} \mathrm{W}$ (Figure 1).

Regionally, the studied area is located between the limits of the geological provinces Coahuila Platform and the Miogeoclinal of the Gulf of Mexico (Ortega-Gutiérrez et al., 1992). The whole studied section belongs to the Eagle Ford Formation, located within the Sabinas Oil Basin (PEMEX, 2010), which corresponds to a rift-type extension pit, associated with the opening of the Gulf of Mexico during the Middle Jurassic (Salvador, 1987). This pit is limited by the Coahuila block to the southwest and by the Tamaulipas block to the northeast, joining the Chihuahua Basin to the northwest and the Paleo-Gulf of Mexico to the southeast (Eguiluz de Antuñano, 2001).

\section{MATERIAL AND METHODS}

The material analyzed comes from a unique stratigraphic section measured and sampled at La Bolita locality, Coahuila. The samples were collected during the bed-by-bed descriptive observation of the lithological and paleontological features of the exposed sequence. The size of the collected samples was approximately $10-15 \mathrm{~cm}$ by $10-15 \mathrm{~cm}$ to warrant a sound sample nucleus and to avoid weathered areas when later processing thin sections.

Thin sections were processed in the facility of the Mexican Geological Survey (SGM by its Spanish initials) at the Centro Experimental Oaxaca, as a couple of large-sized ones, one parallel, the other perpendicular to the bedding plane. For microfacial purpose, thin sections were analyzed under transmitted light microscope. The material herein described (thin sections) is housed in the Paleontological Collection of the SGM, under the abbreviation $\mathbf{L B}$ (for La Bolita) and catalogue numbers from LB-01 to LB-22.

In this study, we follow the criteria of Loeblich \& Tappan (1988), Huber \& Leckie (2011), and Haynes et al. (2015) for the study of planktonic foraminifers. Concerning the 

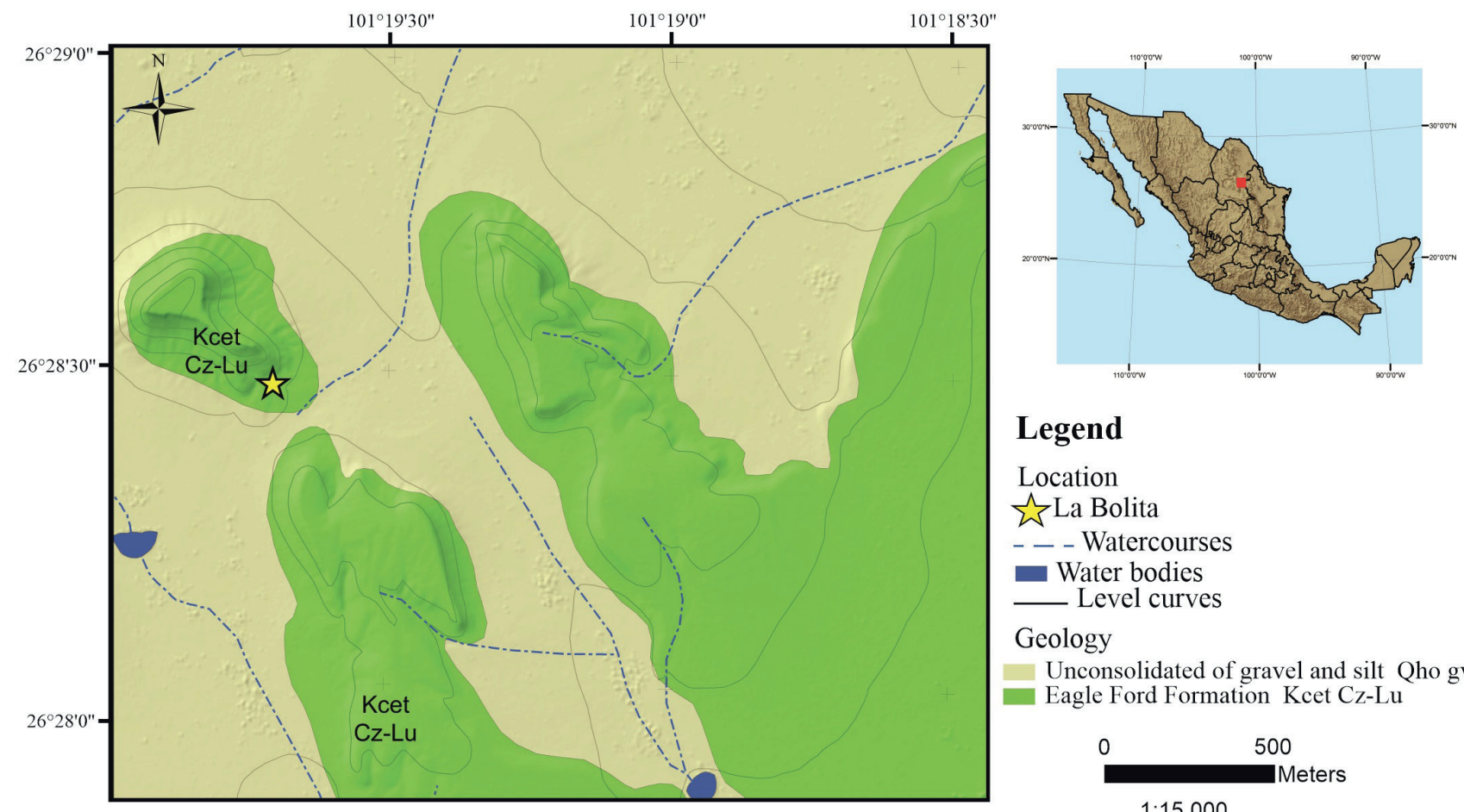

\section{Legend}

Location

$\hat{\Sigma}^{2}$ La Bolita

- - - Watercourses

- Water bodies

Geology

Unconsolidated of gravel and silt Qho gv-lm Eagle Ford Formation Kcet Cz-Lu

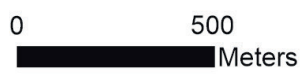

$1: 15,000$

Figure 1. Location of the study area at La Bolita, Castaños municipality, southeastern Coahuila (modified from Romo-Ramírez \& Muñoz-Jarillo, 2017).

identification of calcispheres (as pithonellids and others) we refer to Bonet (1956), Trejo (1983), Elbrächter et al. (2008), and Wendler et al. (2013); while biozonation assignment refers to Caron (1985), Sliter (1989), and Premoli-Silva \& Verga (2004).

\section{RESULTS AND DISCUSION}

\section{Lithostratigraphy}

The studied sequence consists of $31 \mathrm{~m}$ of limestones and clayey limestones interbedded with shaley limestones. Some limestone levels are partially recrystallized with disseminated pyrite. There are also parallel lamination and calcite-filled veins. At the base of this sequence are concentrated many impressions of ammonites, while the rest of the measured section contains some of ammonites, belemnites, and inoceramids.

In general, the limestone and clayey-limestone beds are thin-to-medium, 8 to $30 \mathrm{~cm}$-thick. At the base, the calcareous shale is disposed in thin, 20 to $70 \mathrm{~cm}$-thick, layers, whereas while we observed thick-packed (up to $3.70 \mathrm{~m}$ ) sediments towards the middle-upper part (Figures 2A-D). Based on its megascopic characteristics, we recognized three lithological sets (Figure 3).

\section{Lithological set A (samples LB-01 to LB-02)}

This lithological set consists of $1.11 \mathrm{~m}$ of thin-bedded (14 to $17 \mathrm{~cm}$-thick), slightly clayey limestones, with a dark grey fracture and light brown weathered hue, parallel lamination, veins filled with calcite, and compact structure. It is observed partially recrystallized with scarce disseminated pyrite and noorganic remains. The limestone is interbedded with grey calcareous shale.

\section{Lithological set B (samples LB-04 to LB-16)}

The lithological set B is composed by $24.83 \mathrm{~m}$ of thin-bedded $(6$ to $30 \mathrm{~cm}$ ) limestones, occasionally slightly clayey, with a dark grey-to-black fracture and some greenish and brown hue that turns to light brown-to-reddish when weathered. Its structure is homogeneous and massive, slightly brittle, with scattered metallic minerals (mainly pyrite); parallel lamination and partial recrystallization are observed too, as well as calcite-filled veins and some iron oxides. The limestone is interbedded with dark grey calcareous shale, all thin-bedded in sedimentary sets of up to $3.70 \mathrm{~m}$ thickness. At the base of this sedimentary bundle, there is a level with abundant ammonite casts, while the middle part shows some bivalve remains.

\section{Lithological set $C$ (samples $L B-17$ to $L B-22$ )}

It consists of an alternance of limestone and shale beds, about $5.78 \mathrm{~m}$-thick. The limestone with a dark grey-to-black fracture and a light brown weathered hue is set into thin-tomedium beds (13 to $28 \mathrm{~cm}$ ). This deposit bundle is slightly clayey, partially recrystallized with some calcite-filled veins, and some parallel-laminated layers. Ammonite remains are observed in the middle of this bundle set, whereas its upper part displays fragments of inoceramids (Inoceramus sp.). The shale is dark grey, thin-bedded, and forming medium-to-thick bundle sets $(70$ to $125 \mathrm{~cm})$. 

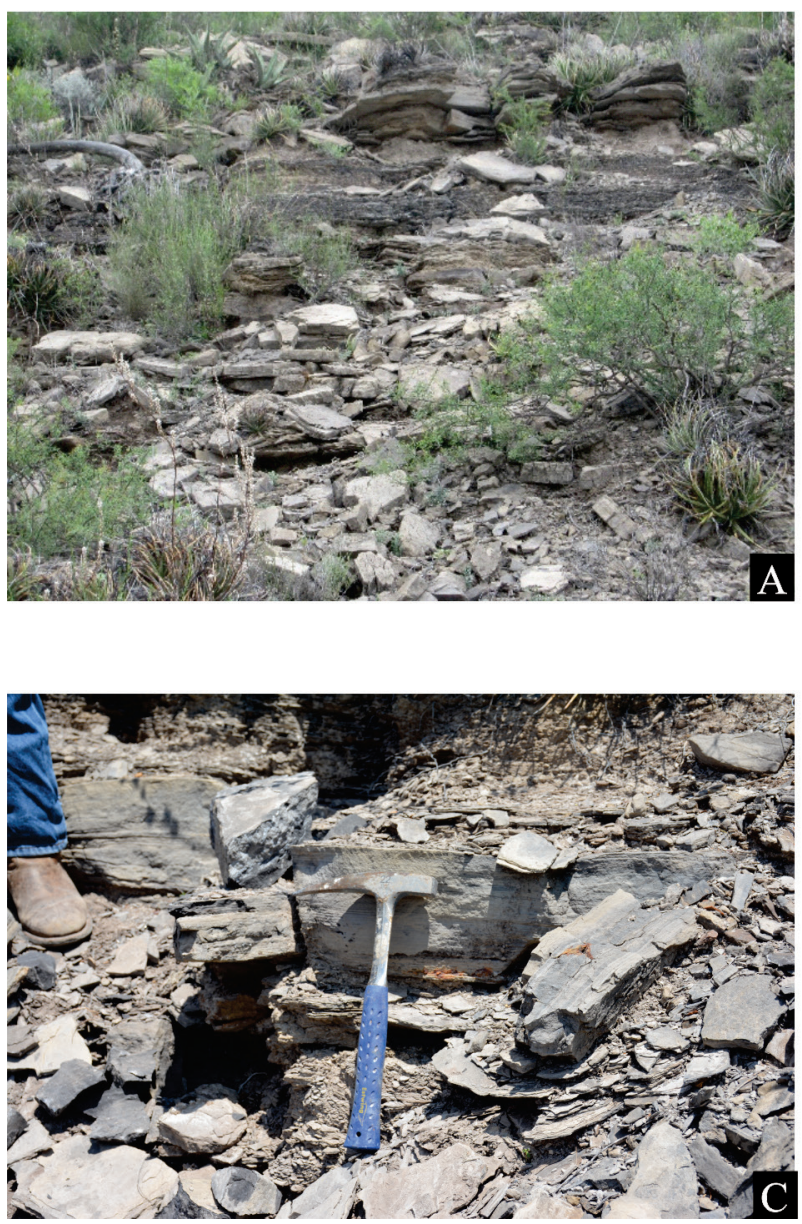
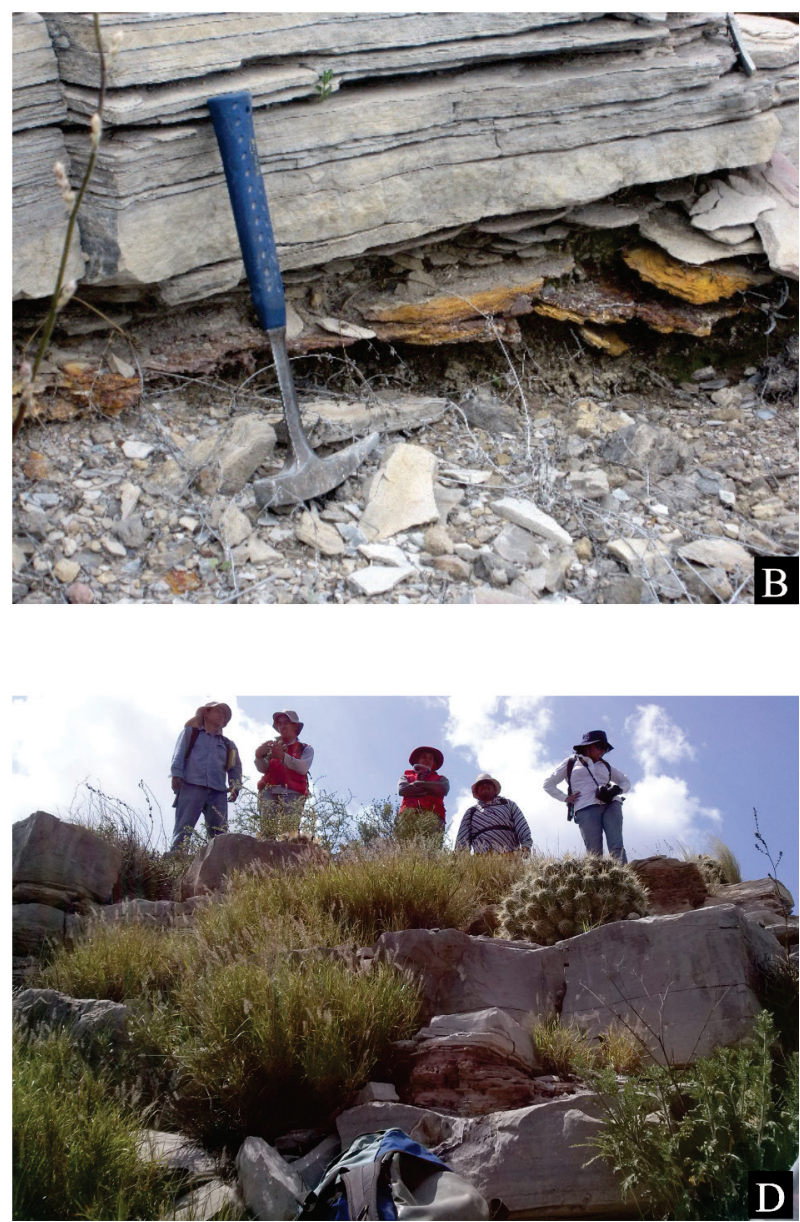

Figure 2. A-B, basal part of the sequence showing the calcareous shale levels; $\mathbf{C}$, detailed view of a clayey limestone; $\mathbf{D}$, upper part of the sequence showing thick limestone beds.

\section{Planktonic microfossil assemblage and age}

The microfossil association is mostly represented by planktonic foraminifers such as hedbergellids (Clavihedbergella, Muricohedbergella, Praeglobotruncana, Whiteinella), globotruncanids (Marginotruncana, Dicarinella), heterohelicids (Planoheterohelix), as well as scarce globigerinelloids (Globigerinelloides).

Planktonic foraminifers consist of: Planoheterohelix moremani (Cushman, 1938), P. reussi (Cushman, 1938), P. globulosa (Ehrenberg, 1840), Globigerinelloides bollii (Pessagno, 1967), Globigerinelloides sp., Muricohedbergella delrioensis (Carsey, 1926), Muricohedbergella sp. (Figure 4), M. planispira (Tapan, 1940), Whiteinella archaeocretacea (Pessagno, 1967), W. aprica (Loeblich \& Tappan, 1961), W. baltica Douglas \& Rankin, 1969, W. brittonensis (Loeblich \& Tappan, 1961), W. inornata (Bolli, 1957), W. paradubia (Sigal, 1952) (Figure 5), Clavihedbergella moremani (Cushman,, 1931), C. simplex (Morrow, 1934), Marginotruncana renzi (Gandolfi, 1942), M. sigali (Reichel, 1950), M. schneegansi (Sigal, 1952), M. pseudolinneiana Pessagno, 1967, Marginotruncana spp., Praeglobotruncana algeriana (Caron, 1966), and Dicarinella canaliculata (Reuss, 1854) (Figure 6).
These planktonic foraminifers are associated with abundant calcitic dinoflagellate cysts (so-called calcispheres: Risserella rablingae Trejo, 1983, Pithonella ovalis (Kaufmann, 1865), Calcisphaerula innominata (Bonet, 1956) and roveacrinid remains (some of them assignable to Roveacrinus Douglas, 1908 (Figure 7), and recrystallized radiolarians.

The microfaunal association shows little variation all through the stratigraphic column (Figure 8 ). The most prominent change is observed in the middle part (samples LB-13 to LB-16), where the content of hedbergellids, and globotruncanids diminishes considerably. Whiteinella and Marginotruncana recovered in the highest part (last $7 \mathrm{~m}$, samples LB-17 to LB-22), while the scarce hedbergellids are represented by a single species (Muricohedbergella planispira). Noteworthy is the restricted occurrence of Calcisphaerula innominata at the base of the sequence.

Due to the controversy over the stratigraphic range of the respective reported species, we focused on the main species, with ranges agreed by most researchers, namely Caron (1985), Sliter (1989), Premoli-Silva \&Verga (2004), and the Mikrotax database (see Huber \& Petrizzo, 2016).

Based on the co-occurrence Marginotruncana schneegansi and Praeglobotruncana algeriana, we suggest a Turonian 


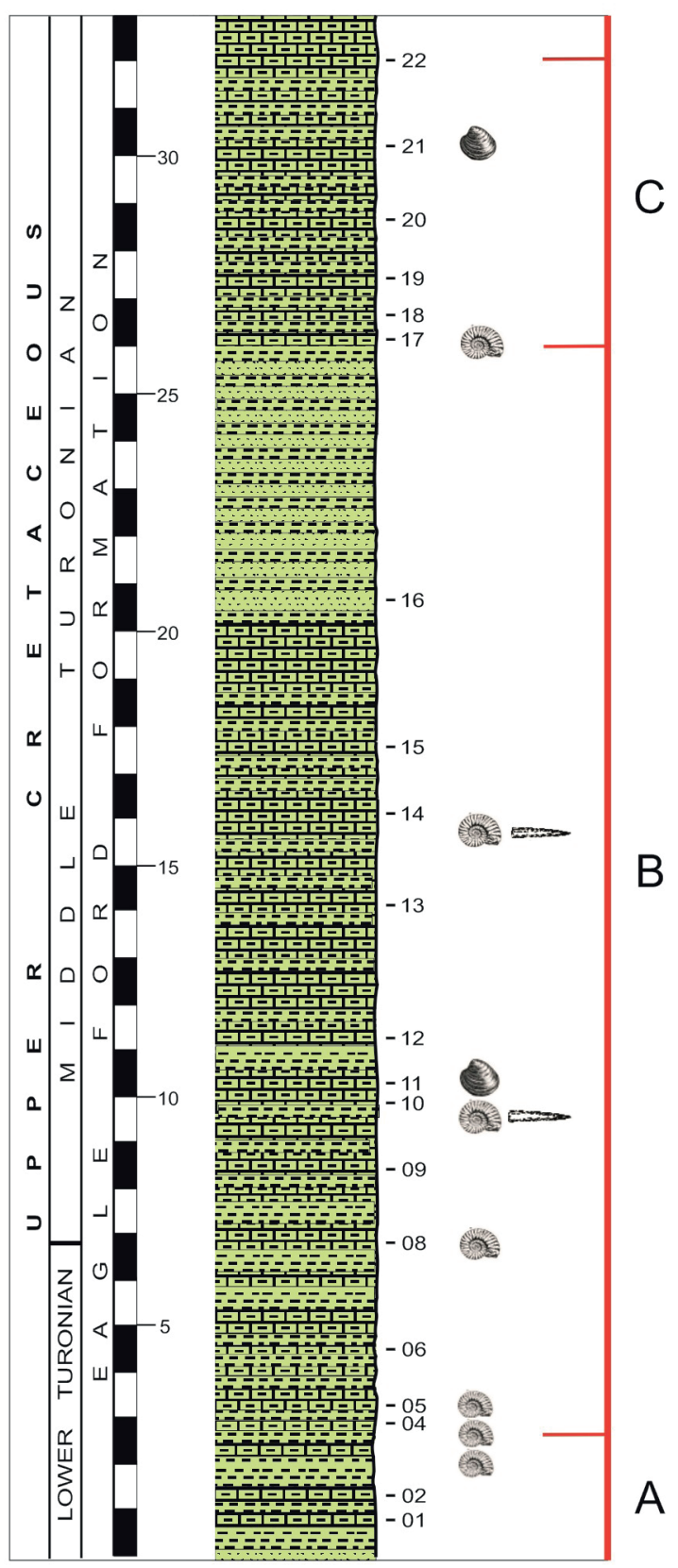

\section{LEGEND}
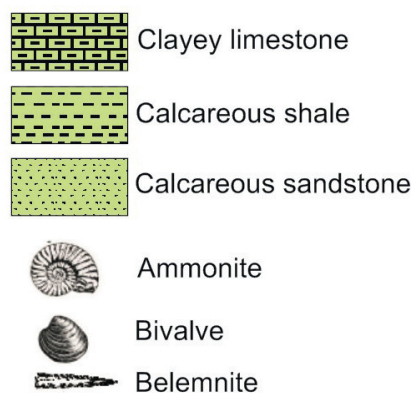

Figure 3. Stratigraphic column of the Eagle Ford Formation in La Bolita outcrop. Keys LB-1 to LB-22 represent the sampled levels; A-C, represent differentiated lithological sets. age for the whole studied sediments (La Bolita outcrop) corresponding to the Eagle Ford Formation.

In particular, the presence of M. schneegansi (sample LB09) in the middle part of the sequence indicates the base of the middle Turonian. This age is consistent with the rest of the sequence (samples LB-10 to LB-22) due to the last occurrence of Praeglobotruncana algeriana, also corresponding to the middle Turonian (Caron, 1985; Sliter, 1989; Premoli-Silva \& Verga, 2004).

The microfaunal assemblages and the inferred age all are congruent with an assignment to the Helvetoglobotruncana helvetica Total Range Zone as recognized for Mexico by Aguilera-Franco (2002) and Omaña-Pulido (2012). This biozone is also characterized by the first appearance and diversification of the genus Marginotruncana, and the reappearance of large and robust planktonic foraminifers: $M$. coronata, M. marianosi, M. pseudolinneiana, M. schneegansi, and M. sigali (Premoli-Silva \& Verga, 2004; Premoli-Silva \& Sliter, 1981; Sliter, 1989; Robaszynski \& Caron, 1979).

In the Guerrero-Morelos Basin particularly, the Helvetoglobotruncana helvetica Zone (early-middle Turonian) is characterized by the first occurrence of the eponymous index species, the presence of dicarinellids, praeglobotruncanids, whiteinellids, hedbergellids, scarce radiolarians and calcispheres, and an increase of keeled planktonic foraminifers (Aguilera-Franco, 2003). However, the index species has not been evidenced so far, hampering to recognize this biozonal range in La Bolita.

\section{Sedimentary paleoenvironment}

The most used fossil group in environmental interpretations is undoubtedly the foraminifera (Lipps, 1979a). In particular, planktonic foraminifers have been used in biostratigraphic correlations and paleoceanographic reconstructions, while its paleoecologic value has been neglected, mainly to infer paleotemperatures and paleobathymetry (Lipps, 1979b). The analysis of planktonic foraminifers, considering the biological, biogeochemical, ecological, and sedimentological processes related to them; provide powerful tools to reconstruct ancient marine systems and climatic conditions (Schiebel \& Hemleben, 2005). To do that, information about their habitat including their horizontal and vertical distribution in the water column is needed (Kretschmer et al., 2018).

Because planktonic foraminifers are very sensitive to physical and chemical variations, both down vertically in the water column and latitudinally, they are considered excellent environmental indicators (Cita \& Premoli-Silva, 1978; Keller et al., 2001; Flügel, 2010). Their evolution, diversification, and extinction are generally associated with water column stratification, vertical changes in the trophic structure, temperature, density gradient, and the differentiation of respective ecological niches (Price \& Hart, 2002; Keller, 2003; Keller \& Pardo, 2004).

Planktonic foraminifers live under relatively restricted conditions of temperature, salinity, and water depth (Cita \& Premoli-Silva, 1978; Arellano-Torres, 2003; Molina, 2004) since they are adapted to different oceanic 

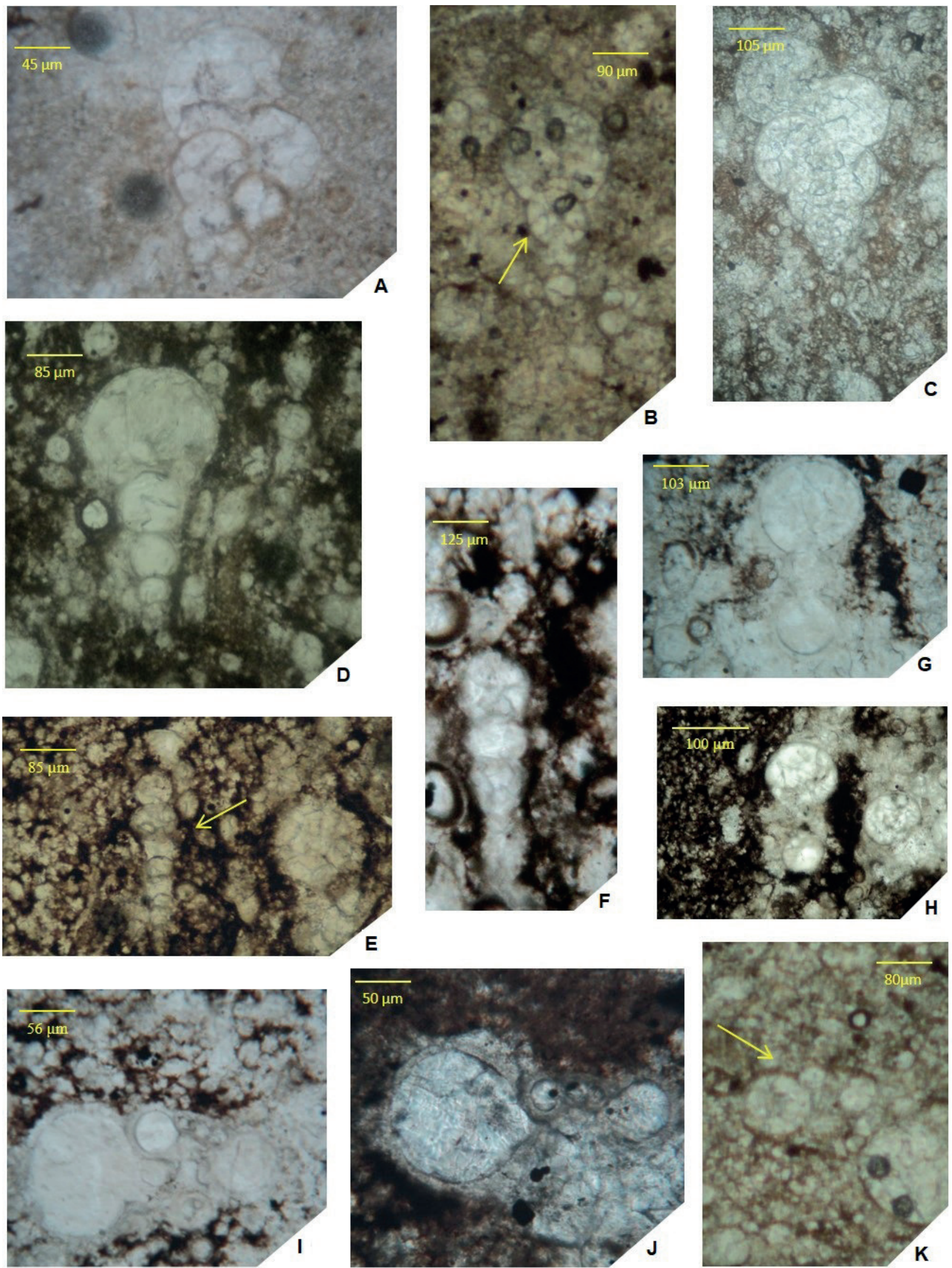

Figure 4. Microphotographs of planktonic foraminifers. A, D, Planoheterohelix globulosa, equatorial and axial sections respectively. B-C, Planoheterohelix reussi, equatorial and axial sections respectively. E-F, Planoheterohelix moremani, axial section. G-H, Globigerinelloides bollii, axial section. I-J, Muricohedbergella delrioensis, axial section. K, Muricohedbergella sp., axial section. 

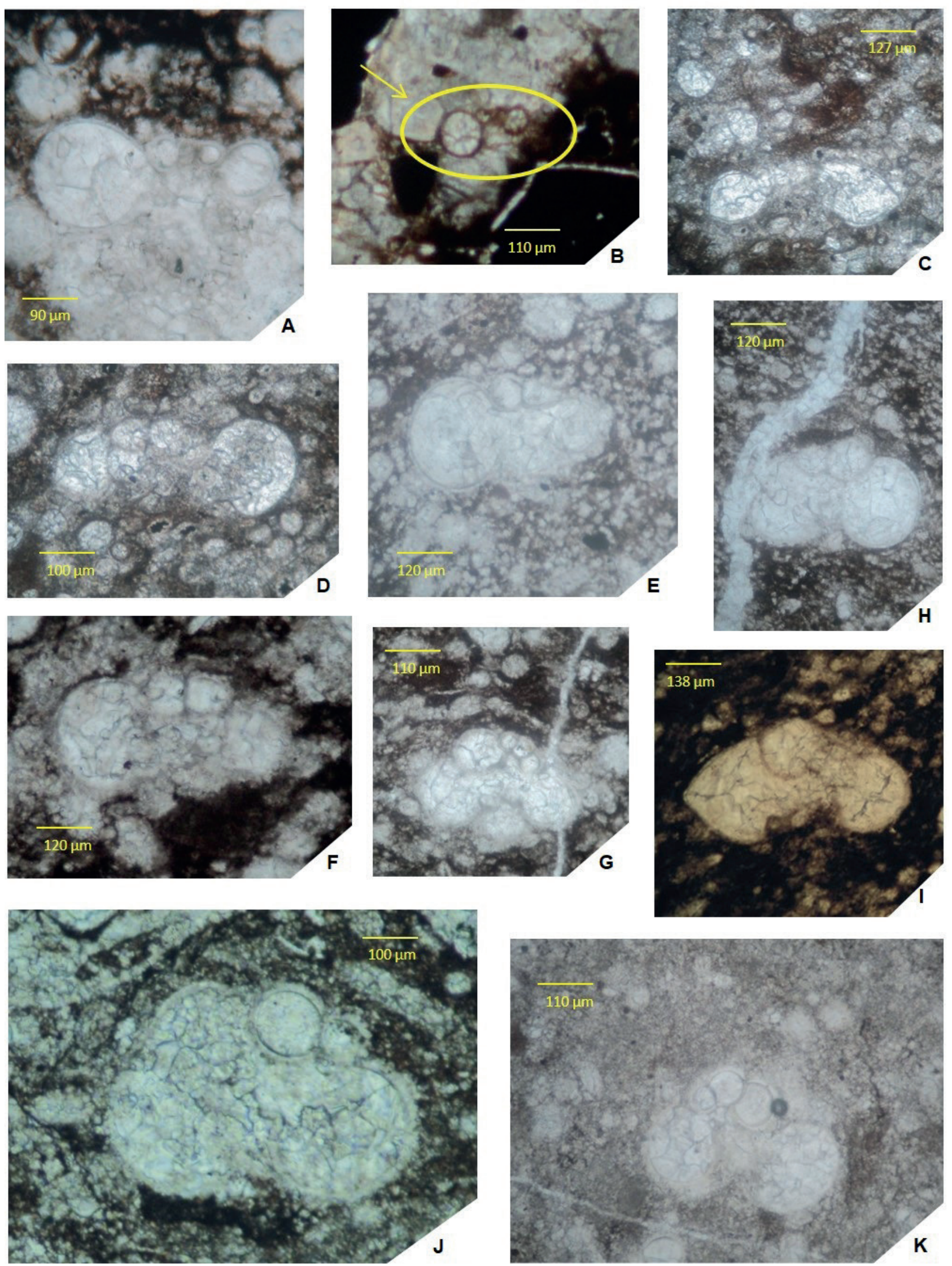

Figure 5. Microphotographs of planktonic foraminifers. All axial sections. A-B, Muricohedbergella planispira. C, Whiteinella archaeocretacea. D, Whiteinella aprica. $\mathbf{E}-\mathbf{F}$, Whiteinella baltica. G-H, Whiteinella brittonensis. I, Whiteinella inornata. J-K, Whiteinella paradubia. 

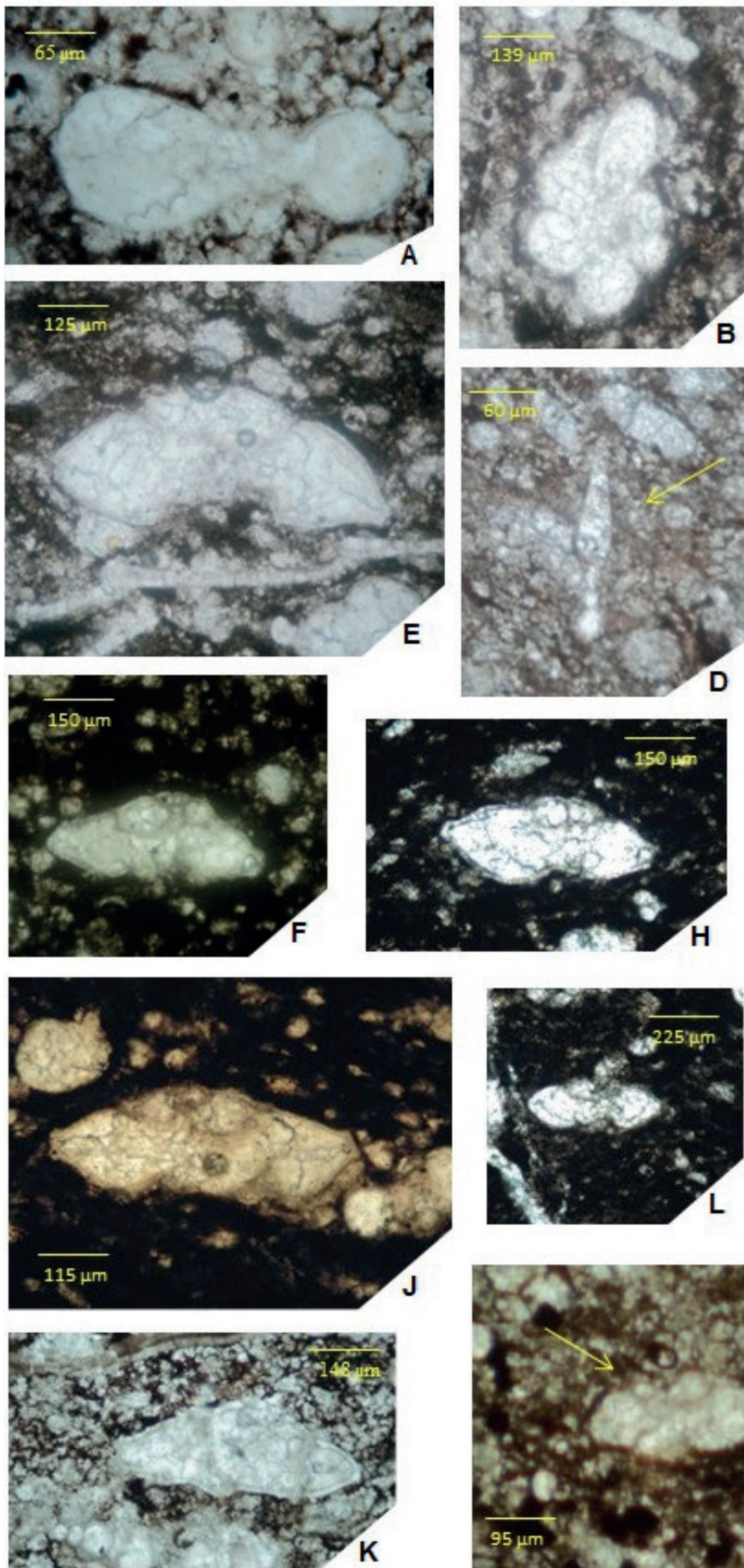
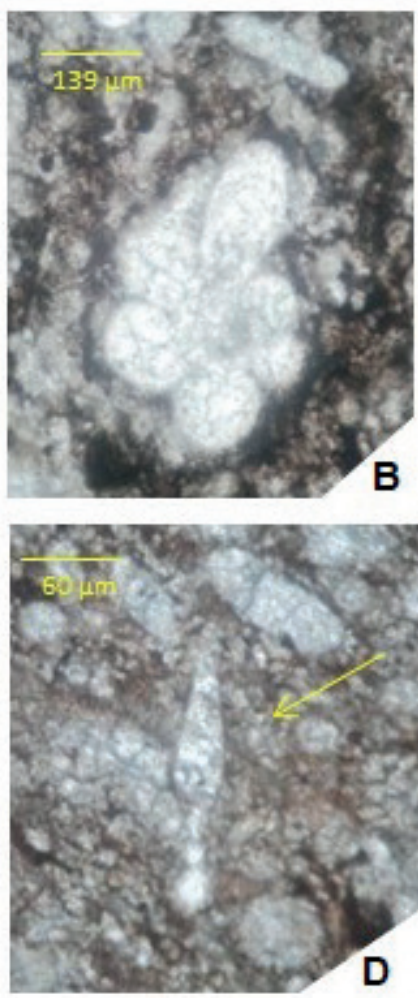

D
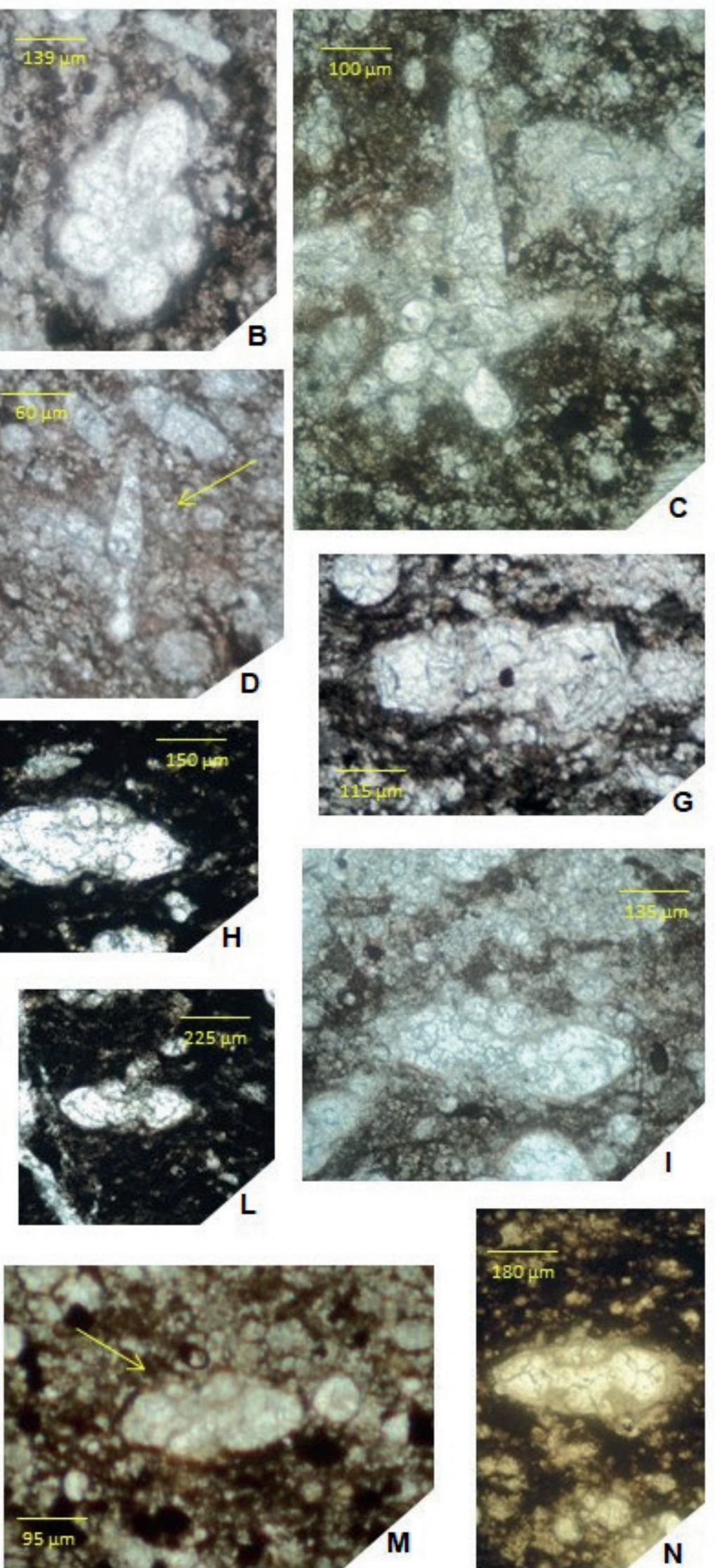

Figure 6. Microphotographs of planktonic foraminifers. A-B, Clavihedbergella simplex, axial and equatorial sections respectively. C-D, Clavihedbergella moremani, equatorial and axial sections respectively. E-F, Marginotruncana sigali, axial section. G, Marginotruncana pseudolinneiana, axial section. H-I, Marginotruncana schneegansi, axial section. J, Marginotruncana renzi, axial section. K, Marginotruncana sp., axial section. L-M, Praeglobotruncana algeriana, axial section. $\mathbf{N}$, Dicarinella canaliculata, axial section. 

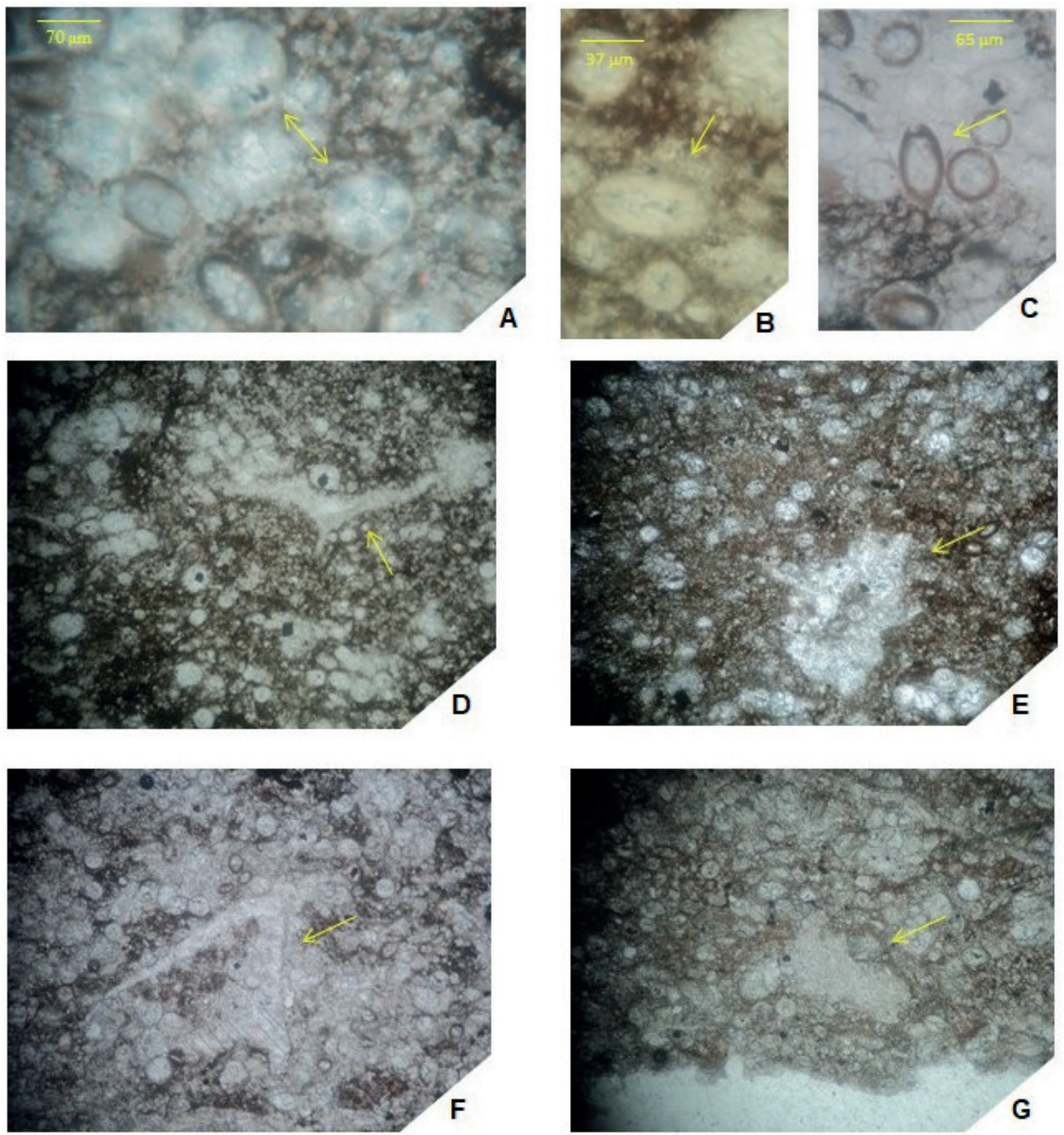

Figure 7. Microphotographs of calcispheres and roveacrinid ossicles. A, Calcisphaerula innominata. B, Pithonella ovalis, axial and transverse sections. C, Risserella rablingae, axial and transverse sections. D, Roveacrinus sp., probable tangential/transverse section of a theca (Tg/TS-?Theca), 10x, E, Roveacrinus sp., squashed oblique section of atheca (OblS-Theca), 10x, F, Roveacrinidae indet., tangential section of radial ornament (TgS-Rad), 10x, G, Roveacrinidae indet., tangential section of the first primibrach (TgS-IBr1), 10x.

layers with particular temperature and densities (Flügel, 2010). According to Flügel (2010), most planktonic foraminifers are restricted to marine salinities from 30 to $40 \%$, and the temperature-controlled species exhibit particular morphological characteristics (shape, size, and whorl direction). Specifically, it has been suggested that foraminifera modify their shape and size, and any frictional drag acting upon them, in direct response to changes in water density and viscosity (Caromel et al., 2014).
The vertical distribution of planktonic foraminifers is related to their respective morphology: the non-keeled forms inhabit shallower waters (less than $50 \mathrm{~m}$ ), the incipient-keeled occupy intermediate waters (between 50 and $100 \mathrm{~m}$ ); whilst keeled forms dwell deeper waters (more than $100 \mathrm{~m}$ ) (Bé, 1977 in Hart \& Bailey, 1979; Aguilera-Franco, 1995; Keller et al., 2001; Molina, 2004; Flügel, 2010).

Planktonic foraminifers in La Bolita are mostly morphotypes devoid of any keel (whiteinellids, hedbergellids, and 


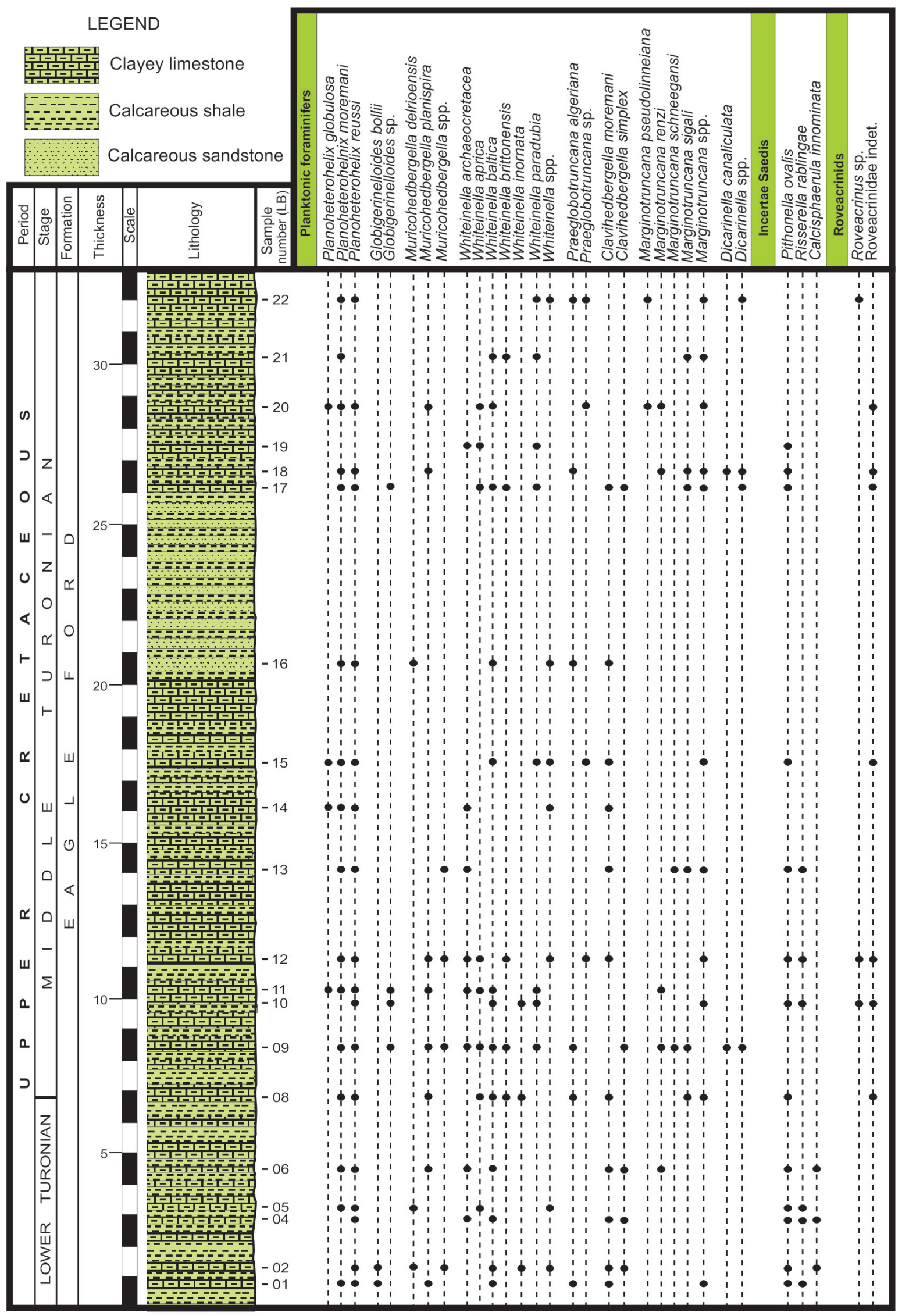

Figure 8. Stratigraphic distribution of taxa in the La Bolita section. 
heterohelicids), whereas keeled forms (helvetoglobotruncanids, dicarinellids, and marginotruncanids) occur subordinately. Microfossil assemblage and lithological features all suggest that the deposition of the Eagle Ford Formation in the La Bolita outcrop took place in an outer platform environment, between 50 and $100 \mathrm{~m}$ water depths, deepening upwards the sequence where diversity and abundance of globular forms dwindle and keeled forms overcome. This is also consistent with the presence of roveacrinids (order Roveacrinida) as small, pelagic, and opportunistic crinoids thriving during sea level rises and subsequent nutrient-flux events (Ferré et al., 2005; Buitrón-Sánchez \& Omaña-Pulido, 2015) in openmarine environments (Ferré et al., 2016).

\section{CONCLUSIONS}

The planktonic foraminifer assemblage identified in the Eagle Ford Formation at La Bolita consists of: Planoheterohelix moremani, P. reussi, P. globulosa, Globigerinelloides bollii, Globigerinelloides spp., Muricohedbergella delrioensis, M. planispira, Muricohedbergella spp., Whiteinella archaeocretacea, $W$. aprica, $W$. baltica, $W$. brittonensis, $W$. inornata, W. paradubia, Whiteinella spp., Clavihedbergella moremani, C. simplex, Marginotruncana renzi, M. sigali, $M$. schneegansi, M. pseudolinneiana, Marginotruncana spp., Praeglobotruncana algeriana, and Dicarinella canaliculata. This microfauna indicates an early to middle Turonian age and suggests an outer platform setting.

\section{ACKNOWLEDGMENTS}

This research was financially supported by the Mexican Geological Survey through the "Geological-Mining Cartography" Program (Geological Mining-Chart Espinazo, G14-A73) and the "Mexican Stratigraphic Lexicon" Project. The authors are very grateful to the reviewers for their valuable advice and useful comments on the preliminary version of the manuscript. We are especially grateful with N. Aguilera-Franco for your constructive comments. Warm thanks are due to R. Contreras-López for his help during the fieldwork and to A. Montiel-Beltrán (Marketing Staff, SGM) for shooting some pictures during surveying.

\section{REFERENCES}

Aguilera-Franco, N. 1995. Litofacies, paleoecología y dinámica sedimentaria del Cenomaniano-Turoniano en el área de Zotoltitlán-La Esperanza, Estado de Guerrero. Facultad de Ingeniería, Universidad Nacional Autónoma de México, Tesis de Maestría, 137 p.

Aguilera-Franco, N. 2003. Cenomanian-Coniacian zonation (foraminifers and calcareous algae) in the Guerrero-Morelos Basin, southern Mexico. Revista Mexicana de Ciencias Geológicas, 20:202-222.

Alvarado-Ortega, J.; Blanco-Piñón, A. \& Porras-Múzquiz, H. 2006. Primer registro de Saurodon (Teleostei: Ichthyodectiformes) en la cantera La Mula, Formación Eagle Ford (Cretácico Superior:
Turoniano), Múzquiz, Estado de Coahuila, México. Revista Mexicana de Ciencias Geológicas, 23:107-112.

Arellano-Torres, E. 2003. Variación del patrón de circulación superficial del Golfo de Tehuantepec determinado por el registro sedimentario de foraminíferos planctónicos durante el Cuaternario Tardio. Posgrado del Instituto de Ciencias del Mar y Limnología, Universidad Nacional Autónoma de México, Tesis de Maestría, 69 p.

Blanco-Piñón, A. \& Alvarado-Ortega, J. 2005. New Derretid fish (Aulopiformes: Teleostei) from the Early Turonian of Vallecillo, NE Mexico. In: J. Poyato-Ariza (ed.) Mesozoic Fishes - Systematics, Homology and Nomenclatura, Universidad Autónoma de Madrid, p. 43-46.

Bolli, H.M. 1957. The genera Praeglobotruncana, Rotalipora, Globotruncana, and Abathomphalus in the Upper Cretaceous of Trinidad, B.W.I. U.S. National Museum Bulletin, 215:51-60.

Bonet, F. 1956. Zonificación Microfaunística de las Calizas Cretácicas del este de México. Boletín de la Asociación Mexicana de Geólogos Petroleros, 8:389-488.

Buitrón-Sánchez, B.E. \& Omaña-Pulido, L. 2015. Roveacrínidos (Crinoidea: Roveacrinida) del Cenomaniano tardío al Turoniano temprano de Cerritos, oeste de la Plataforma Valles-San Luis Potosí, México. Revista de Biología Tropical, 63:17-25. doi:10.15517/rbt.v63i2.23125

Caromel, A.G.M.; Schmidt, D.N.; Phillips, J.C. \& Rayfield, E.J. 2014. Hydrodynamic constraints on the evolution and ecology of planktic foraminifera. Marine Micropaleontology, 106:69-78. doi:10.1016/j.marmicro.2014.01.002

Caron, M. 1966. Globotruncanidae du Crétacé supérieur du synclinal de la Gruyère (Pré alpes médianes, Suisse). Revue de Micropaléontologie, 9:68-93.

Caron, M. 1985. Cretaceous planktic foraminifera. In: H.M. Bolli; J.B. Saunders \& K. Perch-Nielsen (eds.) Plankton Stratigraphy, Cambridge University Press, p. 17-86.

Carsey, D.O. 1926. Foraminifera of the Cretaceous of central Texas. University of Texas Bulletin, 2612:1-56.

Cita, M.B. \& Premoli-Silva, I. 1978. Planktonic foraminifers as ecologic indicators. Examples from the fossil record of the Mediterranean Sea and of the Atlantic Ocean. Italian Journal of Zoology, 45:115-131.

Cushman, J.A. 1931. Hastigerinella and other interesting foraminifera from the Upper Cretaceous of Texas. Contributions from the Cushman Laboratory for Foraminiferal Research, 7:1-86.

Cushman, J.A. 1938. Cretaceous species of Guembelina and related genera. Contributions from the Cushman Laboratory for Foraminiferal Research, 14:2-28.

Douglas, J.A. 1908. A note on some new Chalk crinoids. Geological Magazine, 5:357-359. doi:10.1017/S0016756800138907

Douglas, R.G. \& Rankin, C. 1969. Cretaceous planktonic foraminifera from Bornholm and their zoogeographic significance. Lethaia, 2:185-217. doi:10.1111/j.1502-3931.1969.tb01848.x

Eguiluz de Antuñano, S. 2001. Geologic evolution and gas resources of the Sabinas Basin in Northeastern Mexico. In: C. Bartolini; R.T. Buffler \& A. Cantú-Chapa (eds.) The Western Gulf of Mexico Basin: tectonics, sedimentary basins, and petroleum systems, Tulsa, American Association of Petroleum Geologists, p. 241-270 (Memoir 75). doi:10.1306/M75768C10

Ehrenberg, G.C. 1840. Über die Bildung der Kreidefelsen und des Kreidemergels durch unsichtbare Organismen. Abhandlungen der Königliche Akademie der Wissenschaften zu Berlin, 1838:59-147. 
Elbrächter, M.; Gottschling, M.; Hildebrand-Habel, T.; Keupp, H.; Kohring, R.; Lewis, J.; Sebastian-Meier, K.J.; Montresor, M.; Streng, M.; Versteegh, G.J.M.; Willems, H. \& Zonneveld, K. 2008. Establishing an Agenda for Calcareous Dinoflagellate Research (Thoracosphaeraceae, Dinophyceae) including a nomenclatural synopsis of generic names. Taxon, 57:1289-1303. doi:10.1002/tax.574019

Ferré, B.; Benyoucef, M.; Zaoui, D.; Adaci, M.; Piuz, A.; Tchenar, S.; Meister, C.; Mebarki, K. \& Bensalah, M. 2016. CenomanianTuronian roveacrinid microfacies assemblages (Crinoidea, Roveacrinida) from the Tinrhert area (SE Algeria). Annales de Paléontologie, 102:225-235.

Ferré, B.; Walter, S. \& Bengston, P. 2005. Roveacrinids in MidCretaceous biostratigraphy of the Sergipe Basin, northeastern Brazil. Journal of South American Earth Sciences, 19:259-272. doi:10.1016/j.jsames.2005.01.010

Flügel, E. 2004. Microfacies of carbonate rocks, analysis, interpretation and application. $1^{\text {st }}$ ed. New York, Springer, 976 p. doi:10.1007/978-3-662-08726-8

Flügel, E. 2010. Microfacies of carbonate rocks. $2^{\text {nd }}$ ed. Berlin, Springer, 976 p. doi:10.1007/978-3-642-03796-2

Franco-Rubio, M. 2007. Geología y paleomagnetismo de la porción centro-oriente del estado de Chihuahua, México: definición del lineamiento Delicias-Mulato. Instituto de Geología, Universidad Nacional Autónoma de México, Tesis Doctoral, 35 p.

Gandolfi, R. 1942. Ricerche micropaleontologiche e stratigrafiche sulla Scaglia e sul flysch Cretacici dei Dintorni di Balerna (CantonTicino). Rivista Italiana Paleontologia, 48:1-160.

GEOLEX Database. 2018. Geologic unit: Eagle Ford (online), in National Geologic Map Database. Reston, United States Geological Survey. Available at http://ngmdb.usgs.gov/Geolex/ UnitRefs/EagleFordRefs_8024.html; accessed on: 08/11/2019.

González-Ramos, A.; Barbosa-Luna, D.; Santiago-Carrasco, B.; Izaguirre-Ramos, M.A.; Martínez-Ramos, C.J. \& GraciaValadez, M. 1997. Carta Geológico-Minera Monclova G14-4, escala 1:250,000, estados de Coahuila y Nuevo León. Pachuca, Consejo de Recursos Minerales, $101 \mathrm{p}$.

Hart, M.B. \& Bailey, H.W. 1979. The distribution of planktonic Foraminiferida in the Mid-Cretaceous of NW Europe. Long Beach, International Union of Geological Sciences, p. 527-542 (Series A6).

Haynes, S.J.; Huber, B.T. \& MacLeod, K.G. 2015. Evolution and phylogeny of Mid-Cretaceous (Albian-Coniacian) biserialplanktic Foraminifera. Journal of Foraminiferal Research, 45:42-81. doi:10.2113/gsjfr.45.1.42

Huber, B.T. \& Leckie, R.M. 2011. Planktic Foraminiferal species turnover across deep-sea Aptian/Albian boundary sections. Journal of Foraminiferal Research, 41:53-95. doi:10.2113/ gsjfr.41.1.53

Huber, B.T. \& Petrizzo, M.R. 2016. Microtax: Mesozoic planctonic Foraminifera. The Micropalaeontological Society. Availabe at: www.mikrotax.org/pforams/index.php?dir=pf_mesozoic; accessed on: 08/11/2019.

Ifrim, C.; Stinnesbeck, W. \& Frey, E. 2007. Upper Cretaceous (Cenomanian-Turonian and Turonian-Coniacian) open marine plattenkalk deposits in NE Mexico. Neues Jahrbuch für Geologie und Paläontologie-Abhandlungen, 245:71-81. doi:10.1127/0077-7749/2007/0245-0071

Kaufmann, F.J. 1865. Polythalamien des Seewerkalkes. In: O. Heer (ed.) Die Urwelt der Schweiz, Friedrich Schlothess, p. 194-199.
Keller, G. 2003. Guembelitria-dominated late Maastrichtian planktic foraminiferal assemblages mimic early Danian in central Egypt. Marine Micropaleontology, 47:71-99. doi:10.1016/S03778398(02)00116-0

Keller, G.; Han, Q.; Adatte, T. \& Burns, S. 2001. Paleoenvironment of the Cenomanian-Turonian transition at East bourne, England. Cretaceous Research, 22:391-422. doi:10.1006/cres.2001.0264

Keller, G. \& Pardo, A. 2004. Age and paleoenvironment of the Cenomanian-Turonian global stratotype section and point at Pueblo, Colorado. Marine Micropaleontology, 51:95-128. doi:10.1016/j.marmicro.2003.08.004

Kretschmer, K.; Jonkers, L.; Kucera, M. \& Schulz, M. 2018. Modeling seasonal and vertical habitats of planktonic foraminiferaon a global scale. Biogeosciences, 15:4405-4429. doi:10.5194/bg-15-4405-2018

Lipps, J.H. 1979a. Foraminiferal ecology and paleoecology. In: J.H. Lipps; W.H. Berger; M.A. Buzas; R.G. Douglas \& C.A. Ross (eds.) Foraminiferal ecology and paleoecology, Tulsa, Society for Sedimentary Geology, p. 1-2 (Sort Couse 6). doi:10.2110/ scn.79.06.0001

Lipps, J.H. 1979b. Ecology and paleoecology of planktic Foraminifera. In: J.H. Lipps; W.H. Berger; M.A. Buzas; R.G. Douglas \& C.A. Ross (eds.) Foraminiferal ecology and paleoecology, Tulsa, Society for Sedimentary Geology, p. 62-104 (Sort Couse 6). doi:10.2110/scn.79.06.0062

Loeblich, A.R. \& Tappan, H. 1961. Cretaceous planktonic foraminifera: Part I - Cenomanian. Micropaleontology, 7:257-304.

Loeblich, A.R. \& Tappan, H. 1988. Foraminiferal genera and their classification. New York, Van Nostr and Reinhold Company, 2045 p.

Molina, E. 2004. Micropaleontología. $2^{\text {nd }}$ ed. Zaragoza, Textos Docentes, $704 \mathrm{p}$.

Morrow, A.L. 1934. Foraminifera and Ostracoda from the Upper Cretaceous of Kansas. Journal of Paleontology, 8:186-205.

Omaña-Pulido, M.L. 2012. Bioestratigrafía, Paleoecología y Paleobiogeografía del Cretácico Superior con base en Foraminiferos de la parte Occidental de la Plataforma VallesSan Luis Potosí, México. Instituto de Geología, Universidad Nacional Autónoma de México, Tesis de Doctorado, 198 p.

Ortega-Gutiérrez, F.; Mitre-Salazar, L.M.; Roldán-Quintana, J.; Aranda-Gómez, J.J.; Morán-Zenteno, D.J.; Alanís-Álvarez, S.A. \& Nieto-Samaniego, A.F. 1992. Carta Geológica de la República Mexicana, quinta edición escala 1:2.000,000. Instituto de Geología, Universidad Nacional Autónoma de México; Secretaría de Energía, Minas e Industria Paraestatal, Consejo de Recursos Minerales, 1 mapa.

Pérez-Rodríguez, I. 2013. Biocronoestratigrafía y evolución ambiental del Coniaciense superior al Maastrichtiense con foraminíferos planctónicos. Departamento Ciencias de la Tierra, Universidad de Zaragoza, Tesis Doctoral, 326 p.

Pessagno, E.A. 1967. Upper Cretaceous planktonic foraminifera from the western Gulf Coastal Plain. Palaeontographica Americana, 5:245-445.

Petróleos Mexicanos (PEMEX). 1988. Estratigrafia de la República Mexicana: Mesozoico. Subdirección de Producción Primaria. Distrito Federal, Coordinación Ejecutiva de Exploración, 229 p.

Petróleos Mexicanos (PEMEX). 2010. Las reservas de Hidrocarburos de México. Distrito Federal, Exploración y Producción, Coordinación Ejecutiva de Exploración, 136 p. 
Premoli-Silva, I. \& Sliter, W.V. 1981. Cretaceous Planktonic Foraminifers from the Nauru Basin, Leg 61, Site 462 Western Equatorial Pacific. In: R.L. Larson et al. (eds.) Initial reports of the Deep Sea Drilling Project, 61, United States Government, p. 423-437.

Premoli-Silva, I. \& Verga, D. 2004. Practical manual of Cretaceous planktonic foraminifera. International School on planktonic foraminifera: Cretaceous. In: D. Verga \& E. Rettorim (eds.) International School on planktonic Foraminifera, Universities of Perugia and Milan, $283 \mathrm{p}$.

Price, G.D. \& Hart, M.B. 2002. Isotopic evidence for Early to mid-Cretaceous ocean temperature variability. Marine Micropaleontology, 46:45-58. doi:10.1016/S03778398(02)00043-9

Reichel, M. 1950. Observations sur les Globotruncana du gisement de la Breggia (Tessin). Eclogae Geologicae Helvetiae, 42:591617.

Reuss, A.E. 1854. Beitrage zur Charakteristik der Kreideschichten in den Ostalpen, besonders im Gosauthale und am Wolfgangsee. Denkschriften der Akademie der Wissenshaften. MathematischNaturwissenschaftlichen Klasse Gegründet, 7:1-156.

Robaszynski, F. \& Caron, M. 1979. Atlas of mid-Cretaceous planktonic foraminifera (Boreal sea and Tethys). Cahiers de Micropaléontologie, 1:1-185.

Roemer, F. 1852. Die Kreidebildungen von Texas, und ihre organischen Einschlü. II. Bonn, Adolph Marcus, 100 p.

Romo-Ramírez, J.R. \& Muñoz-Jarillo, C.R. 2017. Informe de la carta geológico-Minera Espinazo, G14-A73, escala 1:50,000, estados de Nuevo León y Coahuila. Pachuca, Consejo de Recursos Minerales, $80 \mathrm{p}$.

Salvador, A. 1987. Late Triassic-Jurassic paleogeography and origin of Gulf of Mexico Basin. American Association of Petroleum Geologists Bulletin, 71:419-451.

Santamaría-Díaz, O.; Orduño, F.A.; Adatte, T.; Ortiz-Ubilla, A.; Riba, A.R. \& Franco, S.N. 1991. Evolución Geodinámica de la Cuenca de Sabinas y sus implicaciones petroleras, estados de Coahuila. Mexico City, Instituto Mexicano del Petróleo, 209 p. (Informe CAO-3508).

Santiago-Carrasco, B.; Barbosa-Luna, D. \& Sabanero-Sosa, M.H. 1998. Carta Geológico-Minera y Geoquímica Reforma G14-A61, escala 1:50,000, estado de Coahuila. Pachuca, Consejo de Recursos Minerales, 54 p.
Schiebel, R. \& Hemleben, Ch. 2005. Modern planktic foraminifera. Paläontologische Zeitschrift, 79:135-148.

Sigal, J. 1952. Aperçu stratigraphique sur la micropaléontologie du Crétacé. Monographies Régionales, 1:3-43.

Silva-Martínez, L.E. 2014. Estratigrafía y microfacies de las capas de la Formación Eagle Ford (Cenomaniano/Turoniano) en el noreste de México: implicaciones paleoecológicas y paleogeográficas. Universidad de Nuevo León, Facultad de Ciencia Biológica, Tesis Doctoral, 172 p.

Sliter, W.V. 1989. Biostratigraphic zonation for Cretaceous planktonic foraminifers examined in thin section. Journal of Foraminiferal Research, 19:1-19. doi:10.2113/gsjfr.19.1.1

Stinnesbeck, W.; Ifrim, C.; Schmidt, H.; Rindfleisch, A.; Buchy, M.C.; Frey, E.; González-González, A.; Vega, F.; Cavin, L.; Keller, G. \& Smith, K.T. 2005. A new lithographic limestone deposit in the Upper Cretaceous Austin Group at El Rosario, county of Múzquiz, Coahuila, northeastern Mexico. Revista Mexicana de Ciencias Geológicas, 22:401-418.

Tappan, H. 1940. Foraminifera from the Greyson Formation of Northern Texas. Journal of Paleontology, 14:93-126.

Trejo, H.M. 1983. Paleobiología y taxonomía de algunos fósiles de México. Boletín de la Sociedad Geológica Mexicana, 44:1-82.

Vega-Vera, F.J.; Nyborg, T.; Rojas-Briceño, A.; Patarroyo, P.; Luque, J.; Porras-Múzquiz, H. \& Stinnesbeck, W. 2007. Upper Cretaceous Crustacea from Mexico and Colombia: similar faunas and environments during Turonian times. Revista Mexicana de Ciencias Geológicas, 24:403-422.

Wendler, J.E.; Wendler, I. \& Huber, B.T. 2013. Revision and evaluation of the Systematic affinity of the Calcitarch genus Pithonella based on exquisitely preserved Turonian material from Tanzania. Journal of Paleontology, 87:1077-1106. doi:10.1666/12-121

Received in 15 May, 2019; accepted in 10 September, 2019. 